\title{
An Empirical Study on the Role of Educational Human Capital in Improving Economic Efficiency ${ }^{1}$
}

\author{
Yan Du \\ Qian $\mathbf{W u} \mathbf{u}^{2}$ \\ Wei Xie \\ Liu Yang \\ School of Economics and Trade \\ Regional Planning and Strategic Research Base of \\ Hunan University of Technology and Business \\ Changsha, China, 410205
}

\begin{abstract}
Under the background of different regional variables, there are differences in the economic effects of human capital. From the perspective of educational human capital, the new normal of economy is taken as the background. Based on 2008 to 2015 provincial panel data in China, this paper first measures the educational human capital and different economic efficiency, and then discusses the effects of educational human capital on technology efficiency, scale efficiency, $X$ efficiency and allocation efficiency, and finally summarizes the difference of the influence of educational human capital on different types of regional economic efficiency. The study found that in the eastern region, the influence of educational human capital on allocation efficiency is most significant; in the central region, the influence of educational human capital on technical efficiency and allocation efficiency is more significant; in the western region, the influence of educational human capital on technical efficiency and allocation efficiency is more significant. And although educational human capital has a positive influence on the improvement of economic efficiency, the significance of the impact is not high, and there are differences with developed countries.
\end{abstract}

Keywords: Educational Human Capital, the New Normal of Economy, Economic Efficiency

\section{Introduction}

The Chinese economy has entered a new normal period from "high-speed growth" to "medium-high-speed growth", and the disappearance of the quantitative "demographic dividend" makes labour-intensive, as a traditional economic growth factor, the driving force of economic growth decreased. At the same time, the way to promote economic growth has shifted from the use of demographic changes to the use of human capital, and the educational human capital has become an important component of human capital in China. However, for a long time, China's research on population and economic growth has focused on the relationship between population growth or population growth rate and economic growth. And there are few studies on the relationship between the dividend of human capital and the quality of economic growth in the dynamic process of population growth.

With the deepening of the theory of economic growth from exogenous to endogenous, knowledge and human capital are introduced into the model of economic growth. According to the Chinese new normal economic situation at present, combining the data of educational human capital, this paper analyzes and measures the economic efficiency of the eastern, central and western regions, and studies the impact mechanism of Chinese educational human capital dividend on economic efficiency. It provides theoretical reference for deepening the reform of China's economic system and formulating the strategy of sustainable population development.

\section{Literature Review}

Studies on the impact of educational human capital on economic efficiency at domestic and foreign are carried out from the following three aspects: the path of economic efficiency improvement, the relationship between human capital and economic growth, and the theory of educational human capital.

\footnotetext{
${ }^{1}$ This study was funded by a research grant from education department of Hunan(18A294), a graduate research innovation grant from Hunan province(CX20190887).

${ }^{2} \mathrm{Qian} \mathrm{Wu}$ is the correspondent author.
} 
In the study of economic efficiency measurement, Solow(1957) attributed the contribution of other factors to the "solow residual value" generated by technological changes, and proposed the "solow residual value method" to measure total factor productivity. The results of Chinese scholar Yu et al. (2006) showed that the city's scale efficiency and pure technical efficiency are positively correlated with the population size of the city. Jin (2007) used malmquist index method to analyze the changes of total factor productivity of 41 major cities in China from 1990 to 2003, and believed that the main path of urban total factor productivity improvement was technological progress, and the growth of city size was negatively correlated with total factor productivity. Dai (2010) used the stochastic frontier model to estimate the total factor productivity of 26 prefecture-level cities and above in China from 2001 to 2007, and found that technological progress is the main driving force for China's urbanization.

In the study of the impact of human capital on economic growth, Abbas \& Peck (2008) used the summed time series data to examine the relationship between human capital and economic growth in Pakistan. It is found that human capital has a positive effect on the ability of the economy to absorb advanced technology. Rao et al. (2009) based on time series data from 1970 to 2002 in Fiji, used the product of education level and average life expectancy as the composite index to measure human capital to make an empirical study, and the results showed that the growth effect of human capital was small, but significant. Toya et al. (2010) used multinational data from 1960 to 1990 to study the relevant impact of human capital on economic growth, and found that human capital is endogenous and negatively affected by economic growth. In China, Xiao (2010) used the spatial panel measurement method to analyze the data of 29 provinces in China from 1990 to 2006, and the results showed that China's human capital and economic growth showed a significant spatial correlation. Li \& Xia (2013) used the extended solow model to study and found that human capital investment and technological progress were the main factors of China's economic growth, and the increase in the number of labor forces has a low impact on economic growth and is gradually decreasing.

In the study of the impact of educational human capital on economic growth, Schultz (1962), an American economist, firstly expounded the key role of human capital on economic growth in theory and pointed out the influence of education on the formation of human capital. Later, Romer $(1962,1986)$ proposed that knowledge accumulation is a new source of economic growth according to the knowledge overflow model, and introduced human capital as an independent factor affecting economic growth into the economic growth driven model. However, Islam (2001) and Pritchett (2002) believed that human capital has nothing to do with economic growth and even has negative effects. It can be seen that there may be a complex non-linear relationship between human capital and economic growth. In countries with different economic levels, there are significant differences in the roles and effects of investment in education. In China, the results of some scholars have confirmed that human capital has a positive effect on economic growth. Shen \& Geng (2001) explained the decisive role of specialized human capital accumulation in the long-term economic growth from the traditional economic growth theory. Liu et al. (2004) believed that the degree of "equalization" of human capital has a significant role in promoting economic growth. The research of Li et al. (2012) showed that if the technological choice of an economy deviates from the optimal structure of its human capital, the economic growth rate of the economy would decrease significantly.

However, most Chinese scholars believe that China's economic growth is mainly driven by material capital, while human capital plays a less significant role. The research of Li (2008) showed that the economic growth in most areas of China is still in the stage of material capital promotion, and the promotion of human capital to economic growth is only significant in a few areas. Qian et al. (2010) examined the impact of human capital on economic growth through the medium of technological innovation, and the results showed that the education level of employees was significantly positively correlated with provincial innovation activities, but the indirect contribution to economic growth was not obvious. There are also Chinese scholars who focused on regional differences in the impact of human capital on economic growth. The research of Wei \& Yu (2009) showed that human capital plays a significant role in promoting economic growth, but there are obvious regional differences in the eastern, central and western regions. Liu \& Jian (2009) investigated the promotion mechanism of human capital on economic growth, and found that the accumulation of human capital could effectively promote the accumulation of social capital, which has a significant positive impact on economic growth. However, this promotion mechanism had a strong regional difference.

In summary, Scholars have a lot of research on the measurement of economic efficiency and the impact of human capital on economic growth, providing extensive evidence for the relationship between human capital and economic growth, but as a result of education investment variable in the economic system of endogenous characteristics of performance, empirical research has not yet reached a consensus conclusion on the role of investment in education and human capital in economic growth. Therefore, the main value of this study is to study the differentiated influence mechanism of educational human capital on economic efficiency in different regions of China based on the provincial panel data from the perspective of educational human capital, which can provide certain theoretical construction for policies to enhance the endogenous development power of economy in the new normal. 


\section{Index selection and data sources}

In this paper, the impacts of educational human capital on the economic efficiency of eastern, central and western regions in China are mainly evaluated by selecting educational human capital as the explanatory variable and technological efficiency, scale efficiency, X efficiency and allocation efficiency as the explanatory variables.

\subsection{Educational human capital}

The length of schooling method is the most widely used method to measure educational human capital. In this paper, the number of years of education per capita is adopted as the measurement standard of educational human capital, and the calculation formula is as follows:

$\mathrm{H}=\sum W_{i} L_{i} / L$

In the formula, $\mathrm{H}$ represents the stock of human capital, $W_{i}$ represents the years of education corresponding to education level i (6 years for primary school, 9 years for junior high school, 12 years for high school, 16 years for bachelor's degree, 19 years for master's degree or above), $L_{i}$ represents the number of people with education level, and $L$ is the number of people aged 6 and above. is the number of people aged 6 and above. The results are shown in Table 1.

Tab.1 Per capita years of education in all provinces of China from 2008 to 2015

\begin{tabular}{lllllllll}
\hline District & 2008 & 2009 & 2010 & 2011 & 2012 & 2013 & 2014 & 2015 \\
\hline Beijing & 10 & 11 & 11 & 14 & 14 & 13 & 13 & 9 \\
Tianjin & 9 & 9 & 9 & 11 & 11 & 11 & 12 & 8 \\
Hebei & 9 & 9 & 9 & 12 & 11 & 11 & 10 & 7 \\
Shanxi & 8 & 9 & 9 & 10 & 10 & 9 & 7 & 8 \\
Neimenggu & 8 & 8 & 9 & 10 & 10 & 10 & 10 & 8 \\
Liaoning & 9 & 9 & 9 & 9 & 8 & 8 & 7 & 8 \\
Jilin & 9 & 9 & 9 & 10 & 11 & 11 & 10 & 8 \\
Heilongjiang & 8 & 9 & 9 & 9 & 9 & 9 & 7 & 8 \\
Shanghai & 10 & 11 & 10 & 11 & 11 & 11 & 10 & 8 \\
Jiangsu & 8 & 8 & 9 & 10 & 9 & 10 & 8 & 8 \\
Zhejiang & 8 & 9 & 9 & 9 & 10 & 10 & 8 & 9 \\
Anhui & 8 & 8 & 9 & 10 & 10 & 10 & 8 & 7 \\
Fujian & 9 & 9 & 9 & 11 & 11 & 12 & 9 & 7 \\
Jiangxi & 9 & 9 & 9 & 11 & 10 & 11 & 10 & 7 \\
Shandong & 9 & 9 & 9 & 10 & 10 & 11 & 11 & 7 \\
Henan & 8 & 8 & 9 & 10 & 8 & 10 & 11 & 8 \\
Hubei & 9 & 9 & 9 & 10 & 10 & 10 & 11 & 8 \\
Hunan & 8 & 9 & 9 & 12 & 13 & 12 & 10 & 8 \\
Guangdong & 9 & 9 & 9 & 9 & 9 & 10 & 11 & 7 \\
Guangxi & 9 & 9 & 9 & 10 & 11 & 10 & 11 & 7 \\
Hainan & 9 & 8 & 9 & 10 & 11 & 13 & 14 & 7 \\
Chongqing & 8 & 8 & 9 & 9 & 10 & 11 & 11 & 7 \\
Sichuan & 8 & 9 & 9 & 10 & 11 & 11 & 10 & 7 \\
Guizhou & 9 & 9 & 9 & 9 & 10 & 10 & 11 & 7 \\
Yunnan & 8 & 8 & 10 & 10 & 10 & 10 & 8 & 7 \\
Xizang & 4 & 4 & 11 & 10 & 10 & 11 & 9 & 8 \\
Shanxi & 9 & 9 & 9 & 11 & 14 & 14 & 9 & 9 \\
Gansu & 8 & 8 & 9 & 12 & 11 & 12 & 9 & 7 \\
Qinghai & 9 & 10 & 9 & 11 & 12 & 11 & 8 & 9 \\
Ningxia & 9 & 10 & 9 & 10 & 10 & 6 & 6 & 7 \\
Xinjiang & 8 & 7 & 9 & 9 & 10 & 10 & 6 & 7 \\
\hline
\end{tabular}

Data source: China population and employment statistics yearbook and China labor statistics yearbook from 2008 to 2015 , which were calculated and sorted out by the author according to the formula. 


\subsection{Economic efficiency}

Economic efficiency can be divided into technical efficiency, scale efficiency, X efficiency and allocation efficiency. Technical efficiency refers to the optimal state between input and output, that is, the ability to maximize output under a certain condition of input. It is also due to the continuous improvement of technology that the output reaches the best level and the utilization rate of resources is also the highest; Scale efficiency means that in a certain period of time, enterprises increase input to expand production scale and the corresponding output quantity is also improved. Due to the moderate expansion of scale, the input cost of production means is reduced, which brings greater economic benefits; X efficiency means to reach the same output level with the minimum cost; Allocation efficiency refers to that under the condition of other conditions being established, the production materials of various inputs are distributed to each output subject to maximize the output. The benefit generated by such distribution is called allocation efficiency. As for the measurement of economic efficiency, as shown in table 2, this paper adopts the calculation method of Wang (2017) and DEA to calculate the technical efficiency, scale efficiency, X efficiency and allocation efficiency.

Tab.2 Variable measurement method and formula

\begin{tabular}{|c|c|c|}
\hline Variables & Measurement method & Formula \\
\hline $\begin{array}{l}\text { Technical } \\
\text { efficiency }\end{array}$ & $\begin{array}{l}\text { The CCR model is } \\
\text { constructed } \\
\text { minimizing the input } \\
\text { Angle }\end{array}$ & $\begin{array}{l}\min _{\lambda_{j} \theta_{j}} \theta_{j}=E 1_{j} \text { s.t } \sum_{j=1} \lambda_{j} X_{i j}-\theta_{j} x_{i 0} \leq 0 \\
\sum_{j=1}^{n} \lambda_{j} y_{i j}-y_{r 0} \geq 0 \lambda \geq 0\end{array}$ \\
\hline Scale efficiency & $\begin{array}{l}\text { Minimize input Angle } \\
\text { to construct VRS } \\
\text { model }\end{array}$ & $\begin{array}{l}\min _{\lambda_{j} \theta_{j}} \theta_{j} s . t \sum_{j=1} \lambda_{j} X_{i j}-\theta_{j} x_{i 0} \leq 0 \\
\sum_{j=1}^{n} \lambda_{j} y_{i j}-y_{r 0} \geq 0 \sum_{j=1}^{n} \lambda_{j}=1 \lambda \geq 0\end{array}$ \\
\hline $\mathrm{X}$ efficiency & $\begin{array}{l}\text { Minimum cost/Actual } \\
\text { cost }\end{array}$ & $\begin{array}{l}\min _{\lambda_{j} \theta_{j}} v_{j}^{\prime} x_{j}^{*} s . t \sum_{j=1} \lambda_{j} X_{i j}-\theta_{j} x_{i 0} \leq 0 \\
\sum_{j=1}^{n} \lambda_{j} y_{i j}-y_{r 0} \geq 0 \lambda \geq 0\end{array}$ \\
\hline $\begin{array}{l}\text { Allocation } \\
\text { efficiency }\end{array}$ & $\begin{array}{l}X \text { efficiency/Technical } \\
\text { efficiency }\end{array}$ & \\
\hline
\end{tabular}

\subsection{Input and output indicators}

Combined with the economic development of various regions in China, the input and output indicators are divided. The results are shown in table 3.The number of employed people in the region and the amount of investment in fixed assets are used as input indicators. The regional GDP, regional fiscal budget revenue, and total regional retail sales are output indicators.

Tab.3 Economic efficiency measurement index system

\begin{tabular}{ll}
\hline Index attribute & Index name \\
\hline Input indicators & The number of employed people in the region \\
& $\begin{array}{l}\text { Investment in fixed assets } \\
\text { Regional GDP }\end{array}$ \\
Output indicators & Revenue within the district budget \\
& The total retail sales of the whole society in the region \\
\hline
\end{tabular}

The data are mainly from China statistical yearbook and provincial statistical yearbook from 2009 to 2016, and part of the data can be obtained through collation and calculation. 


\section{The empirical analysis}

\subsection{Descriptive statistics of variables}

Through statistical analysis of various variables, we can be found that the degree of human capital varies greatly among regions in China, and the maximum number of years of education per capita is 10 years. At the same time, according to the analysis of human capital as the nature of the explanatory variables, the input gap of explanatory variables is also very large. The gap between economic efficiency shows that human capital has different degrees of impact on different regions. There are significant differences in the results of various indicators affecting economic efficiency.

Tab.4 Descriptive statistics for each variable

\begin{tabular}{llllll}
\hline Variables & $\begin{array}{l}\text { Sample } \\
\text { mean }\end{array}$ & Mean & Standard deviation & $\begin{array}{l}\text { Minimum } \\
\text { value }\end{array}$ & $\begin{array}{l}\text { Maximum } \\
\text { Value }\end{array}$ \\
\hline human capital & 248 & 9.362903 & 1.50932 & 4 & 14 \\
$\begin{array}{l}\text { Technical } \\
\text { efficiency }\end{array}$ & 248 & 0.5131855 & 0.1998763 & 0.22 & 1 \\
& & & & & \\
Scale efficiency & 248 & 0.8387581 & 0.1812052 & 0.22 & 1 \\
& & & & 0.04 & 1.5 \\
X efficiency & 248 & 0.4253629 & 0.2286085 & & \\
& & & & 0.25 & 1 \\
$\begin{array}{l}\text { Allocation } \\
\text { efficiency }\end{array}$ & 248 & 0.8208065 & 0.2084844 & & \\
\hline
\end{tabular}

\subsection{Model selection}

The panel data model contains the intercept vector $\alpha$ and explain the variable coefficient vector $\beta$, because of the two variables set different requirements, the model equation is not the same, the panel data model can be divided into: constant coefficient model, variable intercept model, variable coefficient model.

1.The constant coefficient model: In panel data model, selecting the sample not the individual and the change of the structure, vector $\alpha$ and $\beta$ coefficient vector are the same. At this point, according to the estimation model for the constant coefficient model, its general form is:

$y_{i t}=\alpha+x_{i t} \beta+\mu_{i t}, i=1,2,3, \ldots, N, t=1,2,3, \ldots, T$

2. The variable intercept model: In panel data model, selecting the sample data have individual influence but structure remains the same. That is to say, the intercept term is different in the model, but the coefficient vector $\beta$ is the same, so the model is called the variable intercept model. Its general form is:

$y_{i t}=\alpha+x_{i t} \beta+\mu_{i t}, i=1,2,3, \ldots, N, t=1,2,3, \ldots, T$

3. The variable coefficient model: In panel data model, the selected sample data has different individual and structure. That is to say, the intercept term $\alpha$ and the coefficient vector $\beta$ are different. Its general form is:

$y_{i t}=\alpha+x_{i t} \beta+\mu_{i t}, i=1,2,3, \ldots, N, t=1,2,3, \ldots, T$

When estimating with the model, if the model form is selected incorrectly, the measured result will produce errors and even major errors. Therefore, F statistic test and Hausman test are needed to select the most appropriate measure model, and the F statistic is used to determine the choice of the model form, and the Hausman test is used to judge whether the model should be set to a fixed or random impact model.

1. F test

Original hypothesis: $\mathrm{H1}: \beta 1=\beta 2=\beta 3=\ldots=\beta \mathrm{n}$

Alternative hypothesis: $\mathrm{H} 2$ : $\alpha 1=\alpha 2=\alpha 3=\ldots=\alpha \mathrm{n}, \beta 1=\beta 2=\beta 3=\ldots=\beta \mathrm{n}$ 
If $\mathrm{H} 2$ is assumed to be true, $\mathrm{F} 2$ statistic is constructed as follows:

$F_{2}=\frac{\left(S_{3}-S_{1}\right) /[(N-1)(k+1)]}{S_{1} /(N T-N(k+1))} \sim \mathrm{F}[(\mathrm{N}-1)(\mathrm{k}+1), \mathrm{N}(\mathrm{T}-\mathrm{k}-1)]$

In the formula, $S_{3}$ and $S_{2}$ are the sum of squared residuals of the parametric model and the invariant parametric model.

If the F statistic is greater than the corresponding threshold, then reject $\mathrm{H} 2$ and continue to test $\mathrm{H} 1$. On the contrary, it conforms to the constant coefficient model.

If $\mathrm{H} 1$ is assumed to be true, $\mathrm{F} 1$ statistic is constructed as follows:

$F_{2}=\frac{\left(S_{2}-S_{1}\right) /[(N-1)(k+1)]}{S_{1} /(N T-N(k+1))} \sim \mathrm{F}[(\mathrm{N}-1) \mathrm{k}, \mathrm{N}(\mathrm{T}-\mathrm{k}-1)]$

In the formula, $S_{2}$ is the sum of squares of resistantals of the variable intercept model. If the F statistic is greater than the corresponding threshold, then $\mathrm{H} 1$ is rejected, and the variable coefficient model is used. If $\mathrm{H} 1$ is accepted, the variable intercept model is used.

\section{Hausman test}

The test hypothesis of the Hausmann test is:

Original hypothesis $(\mathrm{H} 0)$ : random effects

Alternative hypothesis (H1): Fixed Effect

The test statistic is:

$\mathrm{H}=\left(\beta_{F}^{A}-\beta_{R}\right)^{\prime}\left(\sum_{F}^{A}-{ }_{\Sigma R}\right)^{-1}\left(\beta_{\beta}^{A}-\beta_{R}\right)$

In the formula,,$_{\beta_{F}}$ is the LSDV estimation vector of regression coefficient, ${ }_{\beta_{\pi}}^{A_{R}}$ is the GLS estimation vector of regression

coefficient, $\mathbb{E}_{F}^{\mathbb{A}}$ is the covariance matrix estimator of LSDV estimation coefficient, and $\sum_{R}^{A}$ is the covariance matrix estimator of GLS estimation coefficien

t. Before the specific analysis, the stationarity test and co-integration test of variables should be carried out to avoid the regression analysis of unstable data, so as to avoid the deviation between pseudo-regression and economic reality.

\subsection{Stationarity and co-integration test}

Firstly, stationarity test is conducted for dependent variable educational human capital $(\mathrm{H})$ and independent variable technical efficiency (E1), scale efficiency (E2), X efficiency (E3) and allocation efficiency (E4).The most commonly used unit root test is the LLC test, IPS test, Fisher-ADF and Fisher test, but due to space limitations, only two results are listed in this paper, as shown in table 5. 
Tab.5 Unit root test for variables in different regions

\begin{tabular}{|c|c|c|c|c|c|c|c|c|}
\hline \multirow{3}{*}{ Variables } & \multicolumn{2}{|c|}{ The national } & \multicolumn{2}{|c|}{ The eastern region } & \multicolumn{2}{|c|}{ The central region } & \multicolumn{2}{|c|}{ The western region } \\
\hline & LLC & IPS & LLC & IPS & LLC & IPS & LLC & IPS \\
\hline & test & test & test & test & test & test & test & test \\
\hline \multirow[b]{2}{*}{$\mathrm{H}$} & -23.723 & -3.695 & -3.555 & -1.955 & -3.953 & -1.710 & -15.228 & -2.549 \\
\hline & $* * *$ & $* * *$ & $* * *$ & & $* * *$ & & $* * *$ & $* * *$ \\
\hline \multirow{2}{*}{ D.H } & & -4.247 & & -2.168 & & -2.124 & & -3.156 \\
\hline & & $* * *$ & & & & $* *$ & & \\
\hline E1 & $\begin{array}{l}-11.007 \\
* * *\end{array}$ & $\begin{array}{l}-1.147 \\
* *\end{array}$ & $\begin{array}{l}-4.301 \\
* * *\end{array}$ & -1.014 & $\begin{array}{l}-7.712 \\
* * *\end{array}$ & -0.283 & $\begin{array}{l}-3.942 \\
* * * *\end{array}$ & 0.915 \\
\hline \multirow{2}{*}{ D.E1 } & & -3.464 & & -2.560 & & -1.636 & & -2.552 \\
\hline & & $* * *$ & & $* * *$ & & * & & $* * *$ \\
\hline E2 & $\begin{array}{l}-40.022 \\
* * *\end{array}$ & $\begin{array}{l}-0.945 \\
* *\end{array}$ & $\begin{array}{l}-8.047 \\
* * *\end{array}$ & 0.347 & $\begin{array}{l}-5.248 \\
* * *\end{array}$ & 0.450 & $\begin{array}{l}-44.627 \\
* * *\end{array}$ & -1.944 \\
\hline \multirow{2}{*}{ D.E2 } & & -4.071 & & -1.454 & & -1.892 & & -4105 \\
\hline & & *** & & & & $* *$ & & $-1.10 J$ \\
\hline E3 & $\begin{array}{l}-57.232 \\
* * *\end{array}$ & $\begin{array}{l}-2.693 \\
* * *\end{array}$ & $\begin{array}{l}-2.361 \\
* * *\end{array}$ & 0.768 & $\begin{array}{l}-2.774 \\
* * *\end{array}$ & -1.280 & -35.210 & $\begin{array}{l}-2.586 \\
* * *\end{array}$ \\
\hline \multirow{2}{*}{ D.E3 } & & -6.698 & & -2.429 & & -2.894 & & -4.585 \\
\hline & & $* * *$ & & & & & & \\
\hline E4 & $\begin{array}{l}-10.908 \\
* * *\end{array}$ & $\begin{array}{l}0.728 \\
*\end{array}$ & $\begin{array}{l}-5.314 \\
* * *\end{array}$ & 0.175 & $\begin{array}{l}-7.909 \\
* * *\end{array}$ & 0.164 & $\begin{array}{l}-5.142 \\
* * *\end{array}$ & 0.982 \\
\hline \multirow{2}{*}{ D.E4 } & & & & -1.349 & & - 876 & & -1.482 \\
\hline & & $1.919 * *$ & & & & & & \\
\hline
\end{tabular}

Note: data source: calculated by the author according to the data of per capita years of education; $* * *, * *$ and * respectively represent the significance of regression variables at the levels of $1 \%, 5 \%$ and $10 \%$.

The Coo test was used to perform co-integration tests on the explanatory variables and explanatory variables of the eastern, central and western regions. The results are shown in Table 6.Kao test showed that in the eastern region, the western region and the central region, there was a long-term equilibrium relationship among the variables at the $1 \%$ significance level.

Tab.6 Kao test of variables in different regions

\begin{tabular}{|c|c|c|c|c|c|c|c|}
\hline \multirow[b]{2}{*}{ Statistics } & \multicolumn{7}{|l|}{ T statistic } \\
\hline & The national & $\begin{array}{l}\text { The } \\
\text { region }\end{array}$ & eastern & $\begin{array}{l}\text { The } \\
\text { region }\end{array}$ & central & $\begin{array}{l}\text { The } \\
\text { region }\end{array}$ & western \\
\hline MDF & $\begin{array}{l}-1.660 \\
* *\end{array}$ & $\begin{array}{l}-1.944 \\
* *\end{array}$ & & -0.931 & & -0.446 & \\
\hline DF & $\begin{array}{l}-2.571 \\
* * *\end{array}$ & $\begin{array}{l}-1.564 \\
*\end{array}$ & & $\begin{array}{l}-1.692 \\
* *\end{array}$ & & $\begin{array}{l}-1.747 \\
* *\end{array}$ & \\
\hline $\mathrm{ADF}$ & $\begin{array}{l}-3.947 \\
* * *\end{array}$ & $\begin{array}{l}-2.878 \\
* * *\end{array}$ & & $\begin{array}{l}-2.488 \\
* * *\end{array}$ & & $\begin{array}{l}-1.714 \\
* *\end{array}$ & \\
\hline UDF & $\begin{array}{l}-3.612 \\
* * *\end{array}$ & $\begin{array}{l}-2.572 \\
* * *\end{array}$ & & $\begin{array}{l}-2.236 \\
* *\end{array}$ & & $\begin{array}{l}-2.056 \\
* * *\end{array}$ & \\
\hline UDF & $\begin{array}{l}-3.608 \\
* * *\end{array}$ & $\begin{array}{l}-1.851 \\
* *\end{array}$ & & $\begin{array}{l}-2.361 \\
* * *\end{array}$ & & $\begin{array}{l}-2.692 \\
* * *\end{array}$ & \\
\hline
\end{tabular}

Source of data: Calculated by the author based on data on the number of years of education per capita. ***,**, and $*$ respectively represent the significance of regression variables at the levels of $1 \%, 5 \%$ and $10 \%$.

\subsection{Hausman test}

In order to determine the regression model, a hausman test is also required. The results are shown in Tables 7 to 10. 
Tab.7 Hausman test of educational human capital affecting technical efficiency

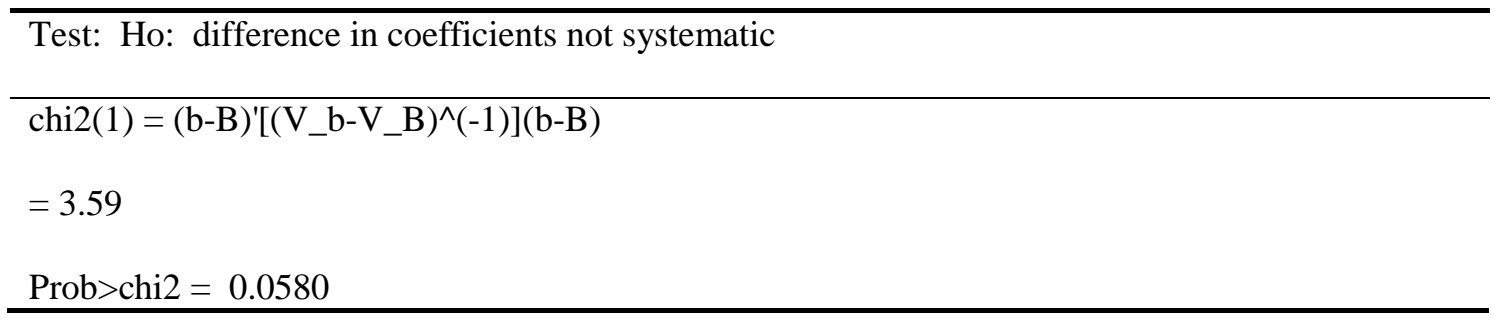

Tab.8 Hausman test of educational human capital affecting scaleefficiency

Test: Ho: difference in coefficients not systematic

chi2(1) $=(\mathrm{b}-\mathrm{B})^{\prime}\left[\left(\mathrm{V} \_\mathrm{b}-\mathrm{V} \_\mathrm{B}\right)^{\wedge}(-1)\right](\mathrm{b}-\mathrm{B})$

$=3.77$

Prob $>$ chi $2=0.0522$

Tab.9 Hausman test of educational human capital affecting $X$ efficiency

Test: Ho: difference in coefficients not systematic

chi2(1) $=(b-B)^{\prime}\left[\left(V_{-} \text {b-V_B }\right)^{\wedge}(-1)\right](b-B)$

$=2.98$

Prob $>$ chi $2=0.0841$

Tab.10 Hausman test of educational human capital affecting allocation efficiency

Test: Ho: difference in coefficients not systematic

chi2(1) $=(\mathrm{b}-\mathrm{B})^{\prime}\left[\left(\mathrm{V} \_\mathrm{b}-\mathrm{V} \_\mathrm{B}\right)^{\wedge}(-1)\right](\mathrm{b}-\mathrm{B})$

$=0.00$

Prob $>$ chi $2=0.9963$

According to the Hausman test, E1, E2, E3, and E4 are tested respectively, and the P values are all greater than 0.01, indicating that the original hypothesis is accepted, and the random effect model is selected to regress the data. And then do regression analysis to explore the effect of educational human capital to improve economic efficiency.

\subsection{Regression result}

According to the multiple regression model of panel data, detailed analysis was performed using Stata14.0 software. When the data is regressed, it is divided into three regions: east, middle and west. When the data is regressed, it is divided into three regions: East, Middle and West. And then we discuss the impact of educational human capital on economic efficiency in each region, and analyze the impact of educational human capital on economic efficiency in various regions. Model regression results as shown in Table 11. 
Tab.11 The influence of educational human capital on Chinese economic efficiency

\begin{tabular}{|c|c|c|c|c|c|}
\hline Districts & Variables & E1 & E2 & E3 & E4 \\
\hline \multirow{3}{*}{ The national } & $\mathrm{H}$ & $-3.07 * * *$ & $-1.15 * *$ & $0.60 *$ & $3.48 * * *$ \\
\hline & Constant & $13.05 * * *$ & $20.65^{* * *}$ & $7.16 * * *$ & $7.58 * * *$ \\
\hline & $\mathrm{R}^{2}$ & 0.0032 & 0.0133 & 0.0216 & 0.0410 \\
\hline \multirow{3}{*}{$\begin{array}{l}\text { The eastern } \\
\text { region }\end{array}$} & $\mathrm{H}$ & -1.21 & -0.50 & 0.79 & $1.95^{*}$ \\
\hline & Constant & $6.86 * * *$ & $13.14 * * *$ & $5.32 * * *$ & $4.69 * * *$ \\
\hline & $\mathrm{R}^{2}$ & 0.0178 & 0.0437 & 0.0785 & 0.0711 \\
\hline \multirow{3}{*}{$\begin{array}{l}\text { The } \\
\text { region }\end{array}$} & $\mathrm{H}$ & $-3.30 * * *$ & -1.42 & -0.41 & $1.78^{*}$ \\
\hline & Constant & $9.34 * * *$ & $14.75 * * *$ & $5.84 * * 8$ & $3.24 * * *$ \\
\hline & $\mathrm{R}^{2}$ & 0.0435 & 0.0445 & 0.0075 & 0.0232 \\
\hline \multirow{3}{*}{$\begin{array}{l}\text { The western } \\
\text { region }\end{array}$} & $\mathrm{H}$ & $-1.85^{*}$ & -0.46 & 0.30 & $1.93 *$ \\
\hline & Constant & $7.71 * * *$ & $10.16 * * *$ & $3.43 * * *$ & $5.00 * * *$ \\
\hline & $\mathrm{R}^{2}$ & 0.0018 & 0.0129 & 0.0011 & 0.0250 \\
\hline
\end{tabular}

Source of data: Calculated by the author based on data on the number of years of education per capita. ***, **, and * respectively represent the significance of regression variables at the levels of $1 \%, 5 \%$ and $10 \%$.

From the national point of view, educational human capital has a positive impact on the improvement of technical efficiency, scale efficiency, X efficiency and allocation efficiency, and has a great influence on technical efficiency and allocation efficiency.

From the point of view of eastern China, the educational human capital has the most significant influence on the allocation efficiency among the improvement of technical efficiency, scale efficiency, X efficiency and allocation efficiency. As the first area to be developed in China, the eastern region has a solid material foundation, superior geographical advantages, abundant natural resources and convenient transportation network.

In terms of deepening regional economic openness and learning from foreign advanced technologies and experience, human capital plays a vital role in improving regional economic efficiency.

From the point of view of central China, the educational human capital is positively correlated with technical efficiency, scale efficiency, X efficiency and allocation efficiency. The influence on technical efficiency and allocation efficiency is more significant than that on X efficiency and scale efficiency. This is because the central region of China has abundant energy and various mineral resources, and most of the province's agriculture is relatively developed, and human capital is more important for technology and productivity. Accelerating the improvement of technical efficiency and allocation efficiency can stimulate the sustained and rapid development of the economy in the central region.

From the point of view of western China, educational human capital plays an important role in promoting the improvement of technical efficiency and allocation efficiency in this area. Due to the limitation of topography and natural conditions, the western region is the most underdeveloped area in China's economic development, with low productivity, primitive farming in many places, and backward in all aspects. Moreover, the regional financial system is not perfect, the degree of marketization is not high, the total amount of investment is small, and the overall economic efficiency is low. Therefore, it is necessary to continuously cultivate human capital through education, absorb and introduce advanced talent technology to promote the continuous improvement of regional economic efficiency.

\section{Conclusion}

\subsection{Research conclusion}

From the perspective of human capital, the Chinese educational human capital is selected as the explanatory variable. The unit root and co-integration test are carried out on the relationship between the four economic efficiency and the 
educational human capital from 2008-2015, and the multiple linear regression of the panel data is established. The regression results show that educational human capital has a positive impact on the improvement of economic efficiency, but the role of educational human capital in economic growth has not been fully exerted. In most areas, the educational human capital does not significantly promote economic growth, and the differences between regions are obvious. Educational human capital in different regions has different effects on economic efficiency. For the whole country, the impact of educational human capital on technical efficiency and allocation efficiency is very large; for the eastern region, the impact of educational human capital on allocation efficiency is most significant; for the western region, the impact of educational human capital on technical efficiency and allocation efficiency is greater.

\subsection{Policy and Recommendations}

According to the calculation of the economic efficiency of China's provinces, combined with the impact of educational human capital on the economic efficiency of different regions, and integrating the economic development status of each region, it is possible to formulate policy recommendations for educational human capital to continue to improve economic efficiency, so as to ensure the full use of regional resources and the overall efficiency of input and output are continue to increase. There are three main aspects of the corresponding policy recommendations.

First of all, China and the region should actively change the mode of economic growth, from focusing on material capital investment to fully utilizing and developing human resources, and enhancing the relative role of human capital to achieve sustained and steady growth of the regional economy. In particular, it is necessary to continue to increase investment in education, improve the accumulation of high-quality human capital, and give full play to the role of educational human capital in the economy.

Secondly, it is necessary for the central government to continue to coordinate the allocation of educational resources, invest more educational resources in key areas and key links, moderately increase investment in education in the central and western regions, and "equalize" educational resources in various regions. Fully release the economic promotion effect of human capital in various regions and achieve scientific and coordinated development.

Finally, to promote the coordinated development of educational human capital and economic society, we must not only further increase the scale of education investment, but also make education investment and human capital accumulation actively adapt to the needs of industrial structure optimization and economic restructuring, and avoid the waste of educational resources. At the same time, we must continue to improve the public education service system, coordinate the allocation of educational resources, promote education equity, and achieve coordinated development of education and economic society.

In short, in theory, human capital investment is a strategic investment and an investment that is more effective than material input. In order to achieve sustained and healthy economic development under the new normal, and to establish an "innovative" country, it is still necessary to give full play to the role of human capital in promoting economic development.

It is necessary to further increase the accumulation of educational human capital, coordinate the allocation of educational resources, improve the quality of education, and form a benign interaction between education investment, human capital formation and economic development, and ultimately bring about the improvement of comprehensive national strength.

\section{References}

Abbas,Q.,\&Peck,J, F. (2008). Human Capital and Economic Growth: Pakistan,1960-2003. the Labor Journal of Economics, 8(13):1-27.

Bian, J, Y., \& Shen, L, S.(2004). An Empirical Analysis of the Influence of Human Capital on the Economic Growth of the East and West of China. Quantitative Economics and Economics Research, 21(12): 19-24.

Cai, Y,X.(2017). An Empirical Study of Human Capital and Economic Growth in China. Zhejiang University of Finance and Economics.

Dai, Y, A. (2010). China's Urbanization Efficiency and its Influencing Factors are Based on the Analysis of Stochastic Frontier Production Function. Quantitative Economics and Economics Research, 2010(12): 103-112.

Hu,H, B.(2014). Research on the Effect of Educational Human Capital on Economic Growth — An Empirical Analysis Based on Sampling Panel Causal Test Method. Educational Research,2014(10):48-56.

Ibrahim, F, W, B. (1994). A Study of Human Capital Investment and Economic Growth, with a Special Reference to the ASEAN Countries. Pullman: Washington State University, 2-3.

Islam, N. (1998). Growth Empirics: A Panel Data Approach. The Quarterly Journal of Economics, 113(1): 325-329. 
Jin, X, Y.(2007). China's Regional Total Factor Productivity and Determinants: 1996-2003. Chinese Population Science, 2007(5): 107-112.

Judson, R. (2002). Measuring Human Capital Like Physical Capital: What Does It Tell Us? . Bulletin of Economic Research, 54(3): 209-231.

Li, D, H., Xia, E, J.(2013). The Impact of Human Capital on China's Economic Growth — Based on the Study of Extended Solow Model. China's Population, Resources and Environment, 23(8):100-106.

Li, F, Y., Ge, Y, H., \& Huang, J, L., (2012). Technical Skill Structure, Human Capital Composition and Economic Gap in China. Chinese Population Science, 2012(4):35-46.

Li, X, M. (2008). Human Capital, Human Capital Structure and Regional Coordinated Development: Evidence from China's Provincial Regions. Journal of Huazhong Normal University, 2008(5): 47-56.

Liu, C, S., \&Jian, Y, F.(2009). Social Capital, Human Capital and Endogenous Economic Growth. Finance and Trade Research, 20(2): 1-9.

Liu, H, Y., Zhao, Y, C., \& Zhang, C, H., (2004). Research on the Relationship between Human Capital's "Homogenization" and China's Economic Growth Quality. Management World. 2004(11):15-21.

Pritchett, L. (2001). Where Has All the Education Gone?. World Bank Economic Review, 15(1581): 367-391.

Qian, X, Y., Chi, W., \& Li, B. (2010). The Influence of Human Capital on China's Regional Innovation and Economic Growth_-An Empirical Study Based on Spatial Measurement. Quantitative Economics and Economics Research, 27(4): 107-121.

Rao, B. ,\&Rupsingh, N, F.(2009). An Extension to the Neoclassical Growth Model to Estimate Growth Effects. Applied Economic Letters, 1(16): 1837-1841.

Romer, P. (1986). Increasing Return and Long-run Growth. Journal of Political Economy, 3(5): 897-910.

Romer, P. (1990). Endogenous Technological Change. Journal of Political Economy,98(98): 71-102.

Schultz, T,W.(1962). Reflections on Investment in Man. The Journal of Political Economy, 70(5): 1-8.

Shen, K, R., \& Geng, Q. (2001). Foreign Direct Investment, Technology Spillovers and Endogenous Economic Growth. Chinese Social Science, 2001(1): 82-93.

Wei, X, H., \& Yu, L, Z. (2009). Human Capital and Regional Economic Growth: Is it just a Linear Relationship?. Financial Science, (10):59-66.

Xiao, X, L. , \&Yao, H, Q. (2012). Research on Total Factor Productivity of Western China Urban Agglomeration: 2001-2010. Economic Research, 42(5): 85-90.

Xiao, Z, Y. (2010). Human Capital, Spatial Spillover and Economic Growth: An Empirical Analysis Based on Spatial Panel Data Model. Financial Science, 10(3): 61-68.

Yu, L, P., Zhou, S, D., \& Wang, A. M.(2006). Study on the Measurement of Urban Economic Efficiency in China. Chinese Population Science, 2006(4): 51-56. 